\title{
Quality Control Assessment of an Ayurvedic Medicine - Durvadi Ghrita
}

\author{
Research Article
}

\section{Sangita Kamaliya ${ }^{1}$, Vaghela D B ${ }^{2}$, Harisha C R ${ }^{3}$, Shukla V J ${ }^{4}$}

\author{
1. PhD Scholar 2. Associate Professor and I/C HOD, Department of Shalakya Tantra, \\ 3. HOD Pharmacognosy Laboratory, 4. HOD Pharmaceutical Chemistry Laboratory, \\ Institute for Post Graduate Teaching and Research in Ayurveda, \\ Gujarat Ayurved University, Jamnagar, Gujarat, India.
}

\begin{abstract}
Background: Durvadi Ghrita is a Sneha Kalpana which is claimed to be effective in Madhumehajanya Timira (Diabetic Retinopathy). In present study, it has been used for Nasya. Objective: Present study was planned to look out on herbal drugs used in the preparation of Durvadi Ghrita and standardization of drug by pharmacognostical and physicochemical parameters and HPTLC evaluation. Methods: Identification and authentication of all the raw drug was done by pharmacognostical study i.e. morphological characters, organoleptic characters and powder microscopy. Physicochemical evaluation and HPTLC of final product were done. Results: Pharmacognostical study of all the raw drugs of Durvadi Ghrita showed presence of oil globule, prismatic crystals of Durva. Lignified branched trichome, pollen grains of Utpala Kinjalaka. Trichome, border pitted vessels of Manjishtha. Collenchyma cells, border pitted vessel of Elvaluka. Lignified fibres, oil globules of Sita. Pitted fibres, pitted vessels of Usheera. Scalariform vessels, prismatic crystals of Musta. Pitted vessels and lignified fibres, crystal fibres of Chandana. Lignified cork, and stone cells of Padmaka etc. Pharmaceutical evaluation of Durvadi Ghrita showed results Specific Gravity 0.9125, Refractive Index 1.47, Acid Value 0.4608, Iodine Value 11.45 and Saponification Value 128.856. High Performance Thin Layer Chromatography, 12 spots were found at $254 \mathrm{~nm}$ and five spots were found at $366 \mathrm{~nm}$. Conclusion: Identification and authentication of herbal drug used in the preparation of Durvadi Ghrita has been done. Pharmacognostical and physicochemical evaluation of prepared drug has been carried out which can be further useful for standardization of Durvadi Ghrita and other clinical researches.
\end{abstract}

Key Words: Diabetic Retinopathy, Durvadi Ghrita, Nasya, Standardization.

\section{Introduction}

Durvadi Ghrita is one of the herbal formulations which described in Ayurvedic text Sahasrayogam- Ghrita Prakarana (1). This preparation contains polyherbal drugs like Durva, Utpala Kinjalaka, Manjistha, Elvaluka, Shweta Chandana, Sita, Musta, Usheera, Padmaka and Rakta Chandana are used as Kalka Dravya, Aja Ksheera and Tandulodaka as Drava Dravya and Aja Ghrita as Sneha Dravya. The Ghrita Paka was done for three days as per classics (2). It is specially indicated in bleeding disorders. Based on its pharmacological properties, it can be used trans- nasally to arrest bleeding seen in Diabetic retinopathy. Diabetic retinopathy (DR) is an important complication of diabetes mellitus (DM) and the leading cause of visual disturbances in developed countries (3). The pathogenesis of DR includes loss of integrity of capillary walls, micro aneurysms, exudations, pericyte loss, endothelial damage, retinal haemorrhages which lead to visual disturbance initially

* Corresponding Author:

Sangita Kamaliya

PhD scholar Department of Shalakya Tantra,

Institute for Post Graduate Teaching and Research in Ayurveda,

Gujarat Ayurved University, Jamnagar, Gujarat, India.

Email Id: sokamaliya@gmail.com and turn in to blindness finally. Durvadi Ghrita has Pittasamana, Raktastambhana and Raktaprasadana properties, can be used in DR specifically to overcome haemorrhage under Urdhvanga Raktapitta spectrum.

Standardization of the drug is very important to assess the quality, purity, safety and efficacy of the drug. Present study, is planned to develop quality parameters of Durvadi Ghrita on the basis of pharmacognostical (microscopic) study, physicochemical study and chromatographic evaluation which is useful for future reference. Hence, there is a need of standardization of quality parameters. Therefore, the present study was designed to evaluate the quality parameters of Durvadi Ghrita.

\section{Materials and Methods Collection of drugs}

Most of the raw drugs for Durvadi Ghrita were procured from the Pharmacy of Gujarat Ayurved University, Jamnagar. Aja Kshreera and Aja Ghrita were procured from local milk man of Jamnagar. Elvaluka and Utpala Patra were collected from Shri Narayana Aushadha Bhandar, Jamnagar. Tandulodaka was prepared in Pharmacy of Gujarat Ayurved University, Jamnagar. According to the guideline of Ayurvedic Pharmacopoeia of India (4), raw drugs were identified and certified and authenticated by individual powder microscopy in Pharmacognosy department I.P.G.T. \& R.A., Jamnagar. 
Table 1: Contents of modified Durvadi Ghrita

\begin{tabular}{|c|c|c|c|c|}
\hline Sr. No. & Drug & Botanical Name & Part used & Quantity \\
\hline 1 & Durva & Cynodon dactylon Linn. & Whole plant & 1part \\
\hline 2 & Utpala Kinjalaka & Nymphaea caerulea Sav. & Stamens & 1 part \\
\hline 3 & Manjistha & Rubia cordifolia Linn. & Whole plant & 1 part \\
\hline 4 & Elvaluka & Prunus cerasus L. & Resin & 1 part \\
\hline 5 & Sita & Sugar (Eng. name) & -- & 1 part \\
\hline 6 & Shweta Chandana & Santalum album Linn. & Stem & 1 part \\
\hline 7 & Usheera & Vetiveria zizanioides Linn. & Root & 1 part \\
\hline 8 & Musta & Cyperus rotundus Linn. & Root & 1 part \\
\hline 9 & Rakta Chandana & Pterocarpus santalinus Linn. & Heart Wood & 1 part \\
\hline 10 & Padmakam & Prunus puddum Roxb. & Heart Wood & 1 part \\
\hline 11 & Aja Ghrita & Goat's ghee (Eng. name) & -- & 4 part \\
\hline 12 & Tandulodaka & Rice water (Eng. name) & -- & 4 part \\
\hline 13 & Aja Ksheera & Goat's milk (Eng. name) & -- & 4 part \\
\hline
\end{tabular}

\section{Preparation of drug}

After getting all the ingredients of Durvadi Ghrita, first of all Aja Ghrita was taken in large vessel. Kalka Dravya of Durva, Utpala Kinjalaka, Manjistha, Elvaluka, Shweta Chandana, Sita, Musta, Usheera, Padmaka and Rakta Chandana were made into bolus of Kalka form by adding sufficient water. This bolus of Kalka was added to Ghrita when it got melted. Then Aja Ksheera and Tandulodaka were added slowly. The ratio of Kalka: Sneha: Drava: Dravya is 1/16: 1: 4. Throughout the procedure the temperature of heating source was maintained. So, as to generate only bubble in the mixture. The heating was continued till Sneha Sidhdha Lakshanas were observed. The mixture was filtered through four folded fine cotton cloth two times after it got partially cooled, and packed in a sterile jar.

\section{Organoleptic characters}

With the help of Panchagyanendriya (Examination by the sense Organs), organoleptic parameters like colour, texture, odour, touch and taste of the finished products were observed and recorded (5).

\section{Powder microscopy}

For Durvadi Ghrita, we used Kalka Dravyas like Durva, Utpala Kinjalaka, Manjistha, Elvaluka, Shweta Chandana, Sita, Musta, Usheera, Padmaka and Rakta Chandana. So, it is difficult to examine and analyse the Durvadi Ghrita to find out the cellular level of raw drugs. Thus, for powder microscopy study, pinch of powder of Kalka Dravya was taken in glass slide covered by cover slip and then stained with phloroglucinol and hydrochloric acid to observe the lignification of the cell wall (6). The sample was studied under the Carl Zeiss Trinocular microscope attached with camera and microphotographs were also taken $(7,8)$.

\section{Physicochemical parameters}

Durvadi Ghrita was analyzed by using various qualitative and quantitative parameters at pharmaceutical chemistry laboratory, IPGT \& RA, GAU, Jamnagar. The common parameters mentioned in Ayurvedic Pharmacopeia of India and CCRAS (9) guidelines i.e. specific gravity(10), refractive index(11), acid value(12), iodine value(13), and saponification value(14) were taken.

\section{High Performance Thin Layer Chromatography (HPTLC)}

Sample preparation $0.1 \mathrm{ML}$ of ghee was taken and $1 \mathrm{ML}$ of hexane was added. The Solution was prepared used for chromatography. Thereafter pre chromatographic derivatization was done. Alcoholic $\mathrm{KOH}$ (base) and thereby heated for 10-15 minutes in CAMAG TLC plate heater. Sample application was done using CAMAG linomat 5. HPTLC of Durvadi Ghrita was carried out using the solvent system petroleum Ether: Diaethyl Ether: Acetic Acid (9:1:0.1v/ v). HPTLC study was performed for the normal phase separation of components of product. Post chromatographic derivatization was done with vanillin sulphuric acid spray reagents (15).

\section{Observations and Results Organoleptic Characters}

Organoleptic characters like colour, odour, taste, touch and texture of Durvadi Ghrita are shown in Table 2.

\section{Table no. 2 - Organoleptic Characteristics of Durvadi Ghrita}

\begin{tabular}{|c|l|l|}
\hline Sr. No. & Characteristics & Results \\
\hline 1 & Colour & Golden Yellow \\
\hline 2 & Odour & Ghee smell \\
\hline 3 & Taste & Sweet Astringent \\
\hline 4 & Touch & Soft \\
\hline 5 & Texture & Thick liquid \\
\hline
\end{tabular}

\section{Microscopic Characters of Durvadi Ghrita}

Pharmacognostical characters of Durvadi Ghrita were observed under the microscope were silica deposits, oil globule, prismatic crystals and epidermal cells with stomata of Durva. Lignified branched trichome, simple fibres, pollen grains and simple starch 
grains with hilum of Utpala Kinjalaka. Trichome, border pitted vessels, starch grain, acicular crystals colouring matters of Manjishtha. Collenchyma cells, cork cells in surface view and border pitted vessel of Elvaluka. Lignified fibres, oil globules, rhomboidal crystals, border pitted vessels of Shita. Pitted fibres, pitted vessels, group of fibres of Usheera. Scalariform vessels, prismatic crystals, oil globules and silica deposits of Musta. Pitted vessels and lignified fibres, crystal fibres, pitted vessels and lignified fibres with oil of Chandana. Lignified cork, simple fibres, crystal fibres and stone cells of Padmaka. Details of which are depicted in plate no: 1 .

\section{Physicochemical analysis}

Result of physicochemical analysis of Durvadi Ghrita; specific gravity, refractive index value, acid value, iodine value and saponification value are shown in Table 3.
Table 3: Physico-chemical parameters:

\begin{tabular}{|l|l|l|}
\hline No. & Parameters & Result \\
\hline 1 & Specific Gravity & $0.9125 \% \mathrm{w} / \mathrm{w}$ \\
\hline 2 & Refractive Index & $1.4700 \% \mathrm{w} / \mathrm{w}$ \\
\hline 3 & Acid value & $0.4608 \% \mathrm{w} / \mathrm{w}$ \\
\hline 4 & Iodine value & $11.458 \% \mathrm{w} / \mathrm{w}$ \\
\hline 5 & Saponification Value & $128.856 \% \mathrm{w} / \mathrm{w}$ \\
\hline
\end{tabular}

\section{High performance thin layer chromatography (HPTLC):}

The colour and $\mathrm{R}_{\mathrm{f}}$ value of resolved sports of HPTLC were noted. HPTLC Results of Durvadi Ghrita showed 12 spots at $254 \mathrm{~nm}$ and 5 spots at $366 \mathrm{~nm}$. Detailed results are shown in the table 4. (Plate no. 2)

Table 4: Rf values obtained by HPTLC

\begin{tabular}{|c|c|c|c|}
\hline Sample & $\begin{array}{c}\text { Detection } \\
\text { Condition }\end{array}$ & $\begin{array}{c}\text { No. of } \\
\text { spots }\end{array}$ & Rf value \\
\hline & $254 \mathrm{~nm}$ & 12 & $\begin{array}{l}0.02,0.05,0.32,0.37,0.42, \\
0.50,0.55,0.59,0.82, \\
\text { Durvadi }\end{array}$ \\
$\begin{array}{c}\text { Ghrita } \\
\end{array}$ & $366 \mathrm{~nm}$ & 5 & $0.02,0.32,0.90$ \\
\hline
\end{tabular}

Plate 1. Powder microscopic photographs of Durvadi Ghrita

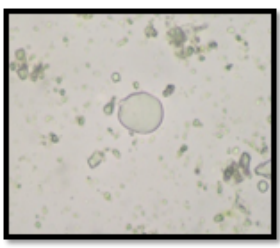

Oil globule of Durva

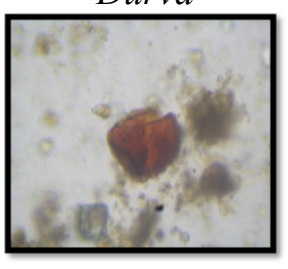

Colouring matter of Manjishtha

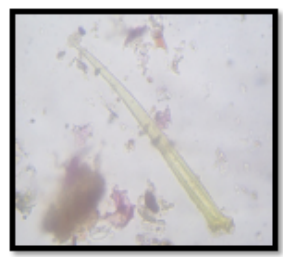

Trichome of Usheera

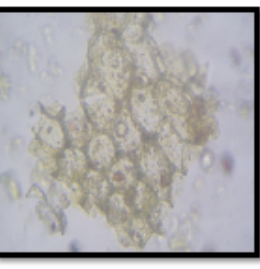

Parenchyma cells Prismatic crystals of Durva

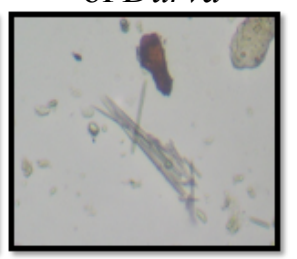

Acicular crystal of Manjishtha

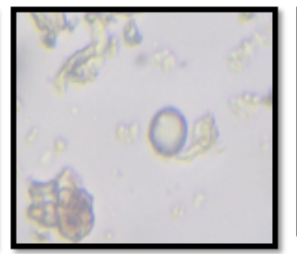

Oil globule of

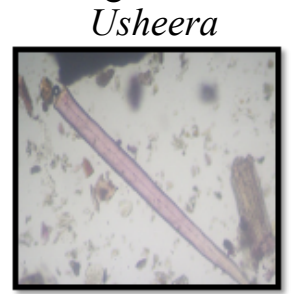

Lignified fibre of Raktachandana

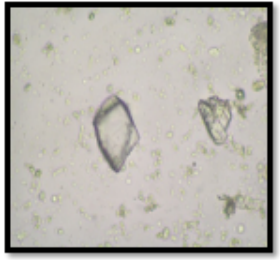

of Durva

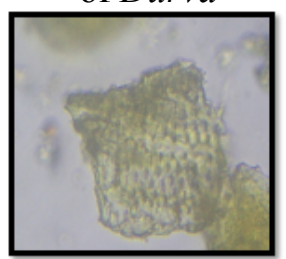

Border pitted vessels of Chandana

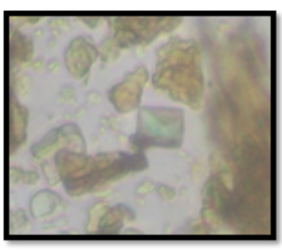

Prismatic crystal of Musta

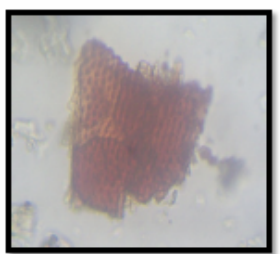

Border pitted vessels of Raktachandana

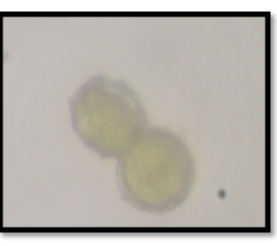

Pollen grains of Utpala

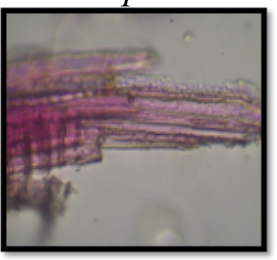

Lignified fibres of Chandana

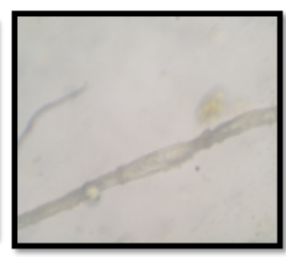

Simple fibre of

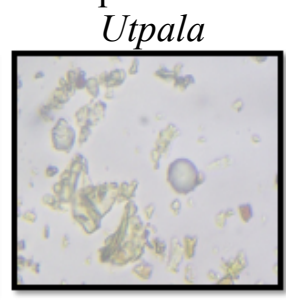

Oil globule of Chandana

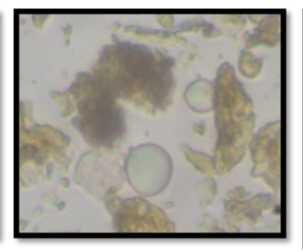

Oil globules of Musta

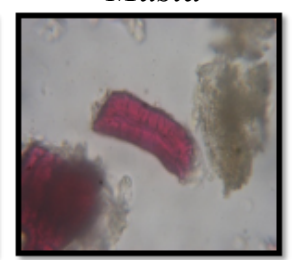

Stone cells of Padmaka

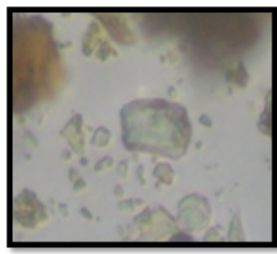

Silica deposition of Musta 
Plate 2. HPTLC of methanolic extract of Durvadi Ghrita observed under short UV Light:

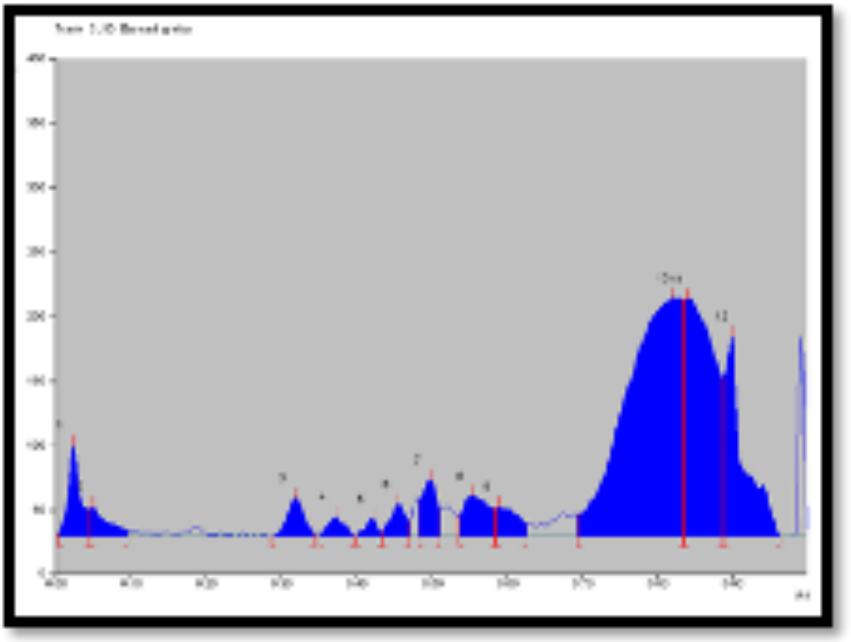

Peak display at $254 \mathrm{~nm}$

\section{Discussion}

In the present study, possible and suitable techniques were taken for the quality evaluation of Durvadi Ghrita. Organoleptic characters like colour, odour, taste, touch and texture of Durvadi Ghrita are according to the raw drugs, used to prepare the medicated Ghrita. The Durvadi Ghrita is golden yellow colour, sweet astringent, soft and viscous liquid with characteristic odour. Authentication of used drugs was done by histological and morphological examination. This can prevent misuse of drug adulteration. The pharmacognostical evaluation showed microscopic characters of all the content which were used in drug preparation. This can prove the purity and quality of finished product.

Specific gravity indicates the presence of solute content in the solvent; the value $(0.9125)$ for the drug was appropriate for this medicated ghee (16). Refractive index indicates the density of sample as compared to air and liquid media and the value found to be 1.4700 of medicated Ghrita was within the limit (17). The value is a measure of the amount of fatty acids in the Ghrita which have been liberated by hydrolysis from the glycerides due to the action of moisture, temperature and/or lipolytic enzyme lipase. It is responsible for rancidity of product; this helps to decide the shelf life of the Ghrita; acid value for Durvadi Ghrita was found to be 0.4608 thus indicating the good stability of the finished product. Iodine value are used to determine the amount of unsaturation in ghee; higher the iodine value, the more unsaturations are present in the ghee. The degree of unsaturation higher will be the possibility of absorption and atmospheric oxidation leading to rancidity (18). The iodine value of Durvadi Ghrita was 11.458 found to be fair enough which indicates the less rancidity of this formulation. The saponification value allows for comparison of the average fatty acid chain length. The long chain fatty acids found in fats have a low saponification value because they have a relatively fewer number of carboxylic functional groups per unit mass of the fat as compared to short chain fatty acids.

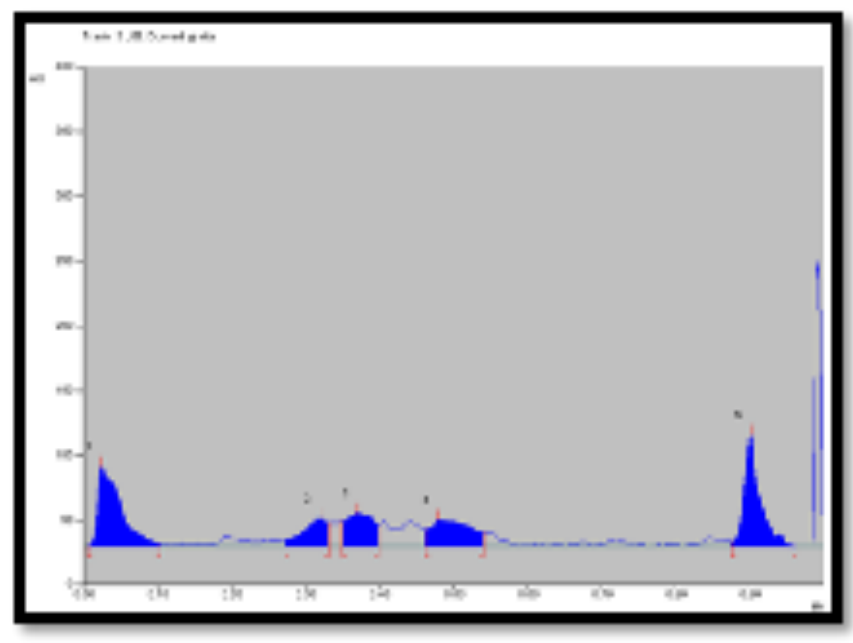

Peak display at $366 \mathrm{~nm}$

In HPTLC of Durvadi Ghrita, twelve major spots were observed at $254 \mathrm{~nm}$ and five major spots were observed at $366 \mathrm{~nm}$ [Table 4, plate 2] indicating its possible compounds of the matrix which may be responsible for its therapeutic activity. These findings could be helpful in identification and authentication of the drug.

\section{Conclusion}

Present study reveals that quality of Durvadi Ghrita as per pharmacognostical and physico chemical parameters, which helps in justifying the quality of formulation and meets the maximum quality and purity standards of the drug. Chromatographic study results suggest presence of active herbal drug in the lipid formulation. On the basis of observations and experimental results, this study may be used as reference standard in the further quality control research work and clinical studies.

\section{References}

1. Krishnan Vaidyan KV, Gopala Pilla S, Sahasrayogam, 26th ed. Alappuzha: Vidyarambham publishers, 2006; 337.

2. Siddhi NM. Bhaishajya Kalpana- Vigyan. Varanasi: Chaukhamba Surbharti Prakashan; 2006. P. 228

3. World Health Organization. Global Health Risks. Mortality and Burden of Disease Attributable to Selected Major Risks. Geneva: World Health Organization, 2009.

4. Ministry of Health \& Family welfare, Anonymous, The Ayurvedic Pharmacopeia of India, First Ed. Part-1, Vol.-5 New Delhi, 2004.

5. Iyengar MA, Pharmacognosy of powdered drugs. Published by Manipal Power Press, Manipal. 1980; 9-43.

6. Khandelwal KR. Practical Pharmacognosy Techniques and Experiments. 9th ed: Nirali Prakashan, Pune, 2002; 24-29: 149-153.

7. Techniques in Microscopy 538, Trees and Evans Pharmacognosy, 15th edition. 1983; 538-547. 
8. Kokate CK, Purohit AP, Gokhale SB Pharmacognosy. 42nd ed. Pune: Nirali Prakashan, 2008: 6.1: 1 .

9. CCRAS, Parameters for qualitative assessment of Ayurveda, Siddha drugs, New Delhi, 2005.

10. Ministry of health and family welfare, Ayurvedic Pharmacopoeia of India, First Edition, Part - 1, Vol - iv, Appendix $3 / 1.3$ Government of India. Department of ayush: Delhi, 2011.

11. Ministry of AYUSH, The Ayurvedic Pharmacopoeia of India, First edition, Part II (Formulation), Volume I, Government of India, New Delhi, Appendix, 2007; 3(3.1): 63.

12. Ministry of AYUSH, The Ayurvedic Pharmacopoeia of India, First edition, Part II (Formulation), Volume I, Government of India, New Delhi, Appendix, 2007; 3(3.12): 75.

13. Ministry of AYUSH, The Ayurvedic Pharmacopoeia of India, First edition, Part II (Formulation), Volume I, Government of India, New Delhi, Appendix, 2007; 3(3.11): 74.
14. Ministry of AYUSH, The Ayurvedic Pharmacopoeia of India, First edition Part II (Formulation), Volume I, Government of India, New Delhi, Appendix, 2007; 3(3.10): 73.

15. Ministry of AYUSH, The Ayurvedic Pharmacopoeia of India, First edition Part II (Formulation) Volume I, Government of India, New Delhi, Appendix, 2007; 3(3.11): 74.

16. Ministry of health and family welfare, Ayurvedic Pharmacopoeia of India, First Edition, Part - 1, Vol - iv, Appendix $3 / 1.3$ Government of India. Department of ayush: Delhi, 2011.

17. Ministry of AYUSH, The Ayurvedic Pharmacopoeia of India, First edition Part II (Formulation) Volume I, Government of India, New Delhi, Appendix, 2007; 3(3.1): 63.

18. Ministry of AYUSH, The Ayurvedic Pharmacopoeia of India, First edition Part II (Formulation) Volume I, Government of India, New Delhi, Appendix, 2007; 3(3.11): 74 . 